\title{
Sale and Leaseback Investment Concepts in Malaysian REIT Companies
}

\author{
Nur Lesya Firsya Johaimi Ling', Mohd Hasrol Haffiz Aliasak¹, Kartina Alauddin² \\ 1 Department of Estate Management, 2 Department of Quantity Surveyor, Faculty of Architecture, Planning \& Surveying, \\ Universiti Teknologi MARA Perak Branch, Seri Iskandar Campus, \\ Seri Iskandar, 32610 Perak, MALAYSIA
}

nurle187@uitm.edu.my, haffiz677@uitm.edu.my, karti540@uitm.edu.my

Tel: +60192804010

\begin{abstract}
Sale and leaseback investment has been a growing trend among the Real Estate Investment Trust (REIT) Companies in Malaysia. This study is to determine the important elements in the concepts of the sale and leaseback transactions practiced by the REIT companies. The study uses the NVIVO software to analyze the data interviews with the REIT managers that adopt sale and leaseback investment transactions. With a response rate of $78 \%$, results show there are three main elements namely location, type of lease, and rental. This study forms a useful guide to real estate managers in developing countries towards using the sale and leaseback as one of the alternative methods in property investment.
\end{abstract}

Keywords: sale and leaseback; property investment; REIT

eISSN: 2398-4287 @ 2019. The Authors. Published for AMER ABRA cE-Bs by e-International Publishing House, Ltd., UK. This is an open access article under the CC BYNC-ND license (http://creativecommons.org/licenses/by-nc-nd/4.0/). Peer-review under responsibility of AMER (Association of Malaysian Environment-Behaviour Researchers), ABRA (Association of Behavioural Researchers on Asians) and cE-Bs (Centre for Environment-Behaviour Studies), Faculty of Architecture, Planning \& Surveying, Universiti Teknologi MARA, Malaysia.

DOI: https://doi.org/10.21834/e-bpj.v4i12.1942

\subsection{Introduction}

Since a decade ago, there exists a new wave of demand among Real Estate Investment Trust (REIT) companies in Malaysia involving the arrangement of sale and leaseback investments, especially in the acquisition of new properties in their portfolio expansion. The traditional form of transaction, which is the direct investment, has transformed into a new generation of indirect investments in the form of sale and leaseback arrangements. It is a relatively straightforward way to raise funds from real estate, in which operator companies intending to unlock their asset values require increased cash flow. They achieve this by selling their properties to REIT companies via sale and leaseback investment arrangements.

Each property acquisition by these Malaysian REITs needs to follow The Guidelines on Listed Real Estate Investment Trusts (Guidelines) issued by the Securities Commission under section 377 of the Capital Markets and Services Act 2007 (CMSA) (SC, 2019). The total number of Malaysian REITs listed on Bursa Malaysia has increased rapidly from 3 in 2004 to 18 in 2016. According to records of listed Real Estate Investment Trusts as of December 31st, 2018, the total net asset value was at RM35million, while market capitalization was RM41million (SC, 2019).

In a sale and leaseback investment, a corporation company sells its asset to a real estate investor but promptly occupies this very same asset by executing a long term lease with the real estate investor, which is a REIT company. However, there are many considerations and risk factors that the REIT companies must be aware of when embarking on sale and leaseback investments. The study thus investigates the elements that the REIT Managers would consider first before purchasing the property under the sale and leaseback arrangement.

\subsection{Purpose of the study}

The investigation in this study focuses on the approaches adopted by Malaysian REIT Managers in purchasing properties through the sale and leaseback investment arrangements. Results of the semi-structured interviews will lead towards the elements in sale and

eISSN: 2398-4287 @ 2019. The Authors. Published for AMER ABRA cE-Bs by e-International Publishing House, Ltd., UK. This is an open access article under the CC BYNC-ND license (http://creativecommons.org/licenses/by-nc-nd/4.0). Peer-review under responsibility of AMER (Association of Malaysian Environment-Behaviour Researchers), ABRA (Association of Behavioural Researchers on Asians) and cE-Bs (Centre for Environment-Behaviour Studies), Faculty of Architecture, Planning \& Surveying, Universiti Teknologi MARA, Malaysia.

DOI: https://doi.org/10.21834/e-bpj.v4i12.1942 
leaseback transactions that need to be considered by the REIT Managers in decision making, especially in expanding their property portfolio.

\subsection{The objective of the study}

In line with the above purpose, this study intends to identify the concepts of the sale and leaseback investments by defining the critical elements that the REIT Managers need to analyze before they embark on the sale and leaseback investment arrangement.

\subsection{Literature Review}

The sale and leaseback investment arrangement is a recent innovation in many financial markets, especially for operation companies. According to Wells, Kyle \& Whitby (2012), and Hunsaker (2012), the main motive of a sale and leaseback arrangement is likely as a method used by an operating company to fund growth, as opposed to covering debt obligations. A sale and leaseback arrangement is also known as a unique financing technique used in real estate market transactions (Ling, 2012), raising money by selling the asset while continuing to use the asset by leasing it back from the buyer. Besides, the capital received in selling the property allows an opportunity for the seller to expand the company's core business. The seller needs to assess the fair price they would receive if they were to sell the properties they own to a buyer who will become their landlord, and subsequently lease the property back (Sanderson, Shakurina, \& Lim, 2019).

Nowadays, there is an overwhelming demand for this type of investment, especially from REIT companies in Malaysia seeking properties to increase their property portfolio. REITs are collective investment schemes involving pooling of funds to be spent primarily on real estate assets and other property-related assets (Hamzah, Rozali, \& Tahir, 2009).

The Securities Commission regulates REITs in Malaysia by introducing the new Guidelines on Listed Real Estate Investment Trusts in January 2005. The Guidelines defines REIT as "a unit trust scheme that invests or proposes to invest primarily in income-generating real estate." REITs generate investment returns from the rental income collected from tenants plus any capital appreciation arising from holding the real estate such as offices, retail spaces, hotels, hospitals, industrial and shopping malls over the period. Most of the Malaysian REITs went for listing after the global financial crisis showing that the performance of the REITs in Malaysia remains profitable (relative to the market portfolio) (Ruslan, 2019).

Hence, these REITs distribute $90 \%$ of their total yearly income to their investors called unitholders in the form of dividends (SC, 2019). This condition protects investors' interests as REITs are supposed to generate stable dividend pay-outs. REITs are typically managed by a professional management company (REIT Manager), which is licensed by the Securities Commission under the Capital Market Services Act 2007 (CMSA). A REIT manager is responsible for the day-to-day management of the REIT, as well as its long-term strategic direction. A REIT involves long-term investment and commitment due to the nature of its returns. Malaysian REIT returns correlate more strongly with long-term rather than short-term interest rate changes in the post-Global Financial Crisis 2008/09 (GFC) period. This lends support to the notion that REITs are a form of long-term investment (Wong, 2015).

There are many considerations and risk factors that REIT companies must be aware of when embarking on sale and leaseback investment arrangements. Every investor may have his/her objectives that influence his/her investment decisions. He/she may be influenced more by factors such as yields, rental growth, or capital growth (Lam \& Tipping, 2016). One of the greatest challenges for the REIT Manager is the need to recognize the importance of acquiring quality properties in making property investment decisions, especially for their property portfolios. This is important to avoid anything happening to their property income in the future that may affect the distribution of income to the unitholders.

Therefore, the REIT Manager needs to identify the concepts of the sale and leaseback investments through determining the critical elements to analyze in efforts to maximize the returns on their property investments before they commit to a sale and leaseback arrangement.

\subsection{Methodology}

The consideration behind this study is to determine the critical elements in the concepts of sale and leaseback transactions practiced by the REIT companies in Malaysia. This study applies the case study approach to gauge their perceptions in the applicability of the important elements in the concepts of sale and leaseback investment arrangements. In line with the methodological approach of qualitative research, the data goes through content and thematic analyses derived from the semi-structured interview analysis.

\subsection{Study Area}

This study conducts a survey only on Malaysian REIT companies involved in sale and leaseback investments. This survey is in the form of semi-structured interviews to solve the issue of limited lands and getting the highest quality buildings for investment. The selection of the participant is directly with the experts in charge of the arrangement of sale and leaseback investments.

\subsection{Data Collection}

There are two phases in the data collection procedure in this study which are: 


\subsubsection{Phase 1: A literature review.}

This study commences with a review of a range of literature on the research topic itself. In particular, it draws upon a limited amount of academic literature either in Malaysia or from world-wide studies, including theoretical and conceptual framework studies. This study deals only with:

i) Malaysian Real Estate Investment Trusts (REITs); and

ii) Sale and leaseback transactions in other countries

\subsubsection{Phase 2: The Main Survey}

A semi-structured interview was conducted on six experts to gauge their perceptions of the key elements in the concepts of sale and leaseback investment. The analysis of data from the interviews uses the content analysis technique.

\section{STEP 1}

Distribution of screening forms during the preliminary survey via email and telephone calls to potential participants to obtain some information.

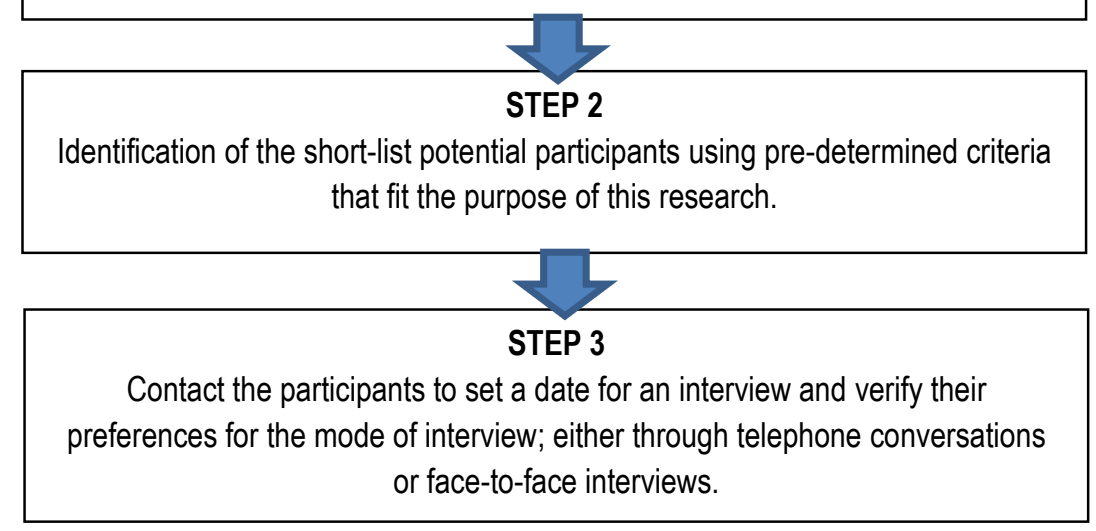

Figure 1: Process of Preliminary Survey

The preliminary survey process is part of the main survey process in this study, as shown in Figure 1. In step 1, the questions prepared were relatively straightforward, aimed at identifying any of the property portfolios from among the 18 REIT companies that are involved in sale and leaseback investment arrangements.

In the next step, shortlist the potential participants according to the pre-determined criteria for the main survey. The main selection criterion of a participant is that only REIT companies experienced in dealing with sale and leaseback arrangements were selected.

In step 3, once the potential participants were selected, the researcher then approaches the participants to request for interview appointments by either telephone calls or email communication. As a consequence of the shortlisting of the participants, only 7 out of 9 REIT companies agree to participate in the main survey. Of these, the same REIT Manager is in charge of 2 REIT companies. Hence, this semi-structured interview exercise involves a total of 6 participants. 5 REIT companies agree to participate through face-to-face semi-structured interviews, while 1 REIT company opts for a telephone interview. The researcher conducts the interviews from October 2018 until March 2019. The number of the interview is considered sufficient and tallies with the minimum sample size ranging from 5 to 25 for semi-structured or in-depth interviews (Saunders, 2016).

The central topic guide includes the following prompts to elicit participants' views and experiences in the elements that the company needs to be aware of before participating in a sale and leaseback investment.

\subsection{Data Analysis Procedure}

The survey interviews were audio-recorded individually with the participants' consent and transcribed onto a paper script. Subsequently, the content of interview transcripts was analyzed using an open coding method with the help of QSR NVIVO Version 12 software. Through NVIVO, the researcher converts the labeled data coding into codes known as nodes that refer to the answers or responses from the interviewees. In other words, a node is a collection of references regarding a specific theme. Gathering of the references is via reading through the sources. References about the same theme are categorized into the corresponding node. This is the coding process (Lu and Yuan, 2011).

Throughout the coding process, the phrases and keywords were analyzed and encoded with suitable category labels and commonalities were developed (Saldana, 2009). Further analysis of the coding process results is possible by using data reduction. Here, the data is split into entities, put into categories (Miles and Huberman, 1994), and themes developed. Then, the themes are reported as the headings in the findings of this study and mapped based on recurring themes. The procedures for data collection and data analysis are as follows in Figure 2. 
Figure 2: Data Collection and Data Analysis

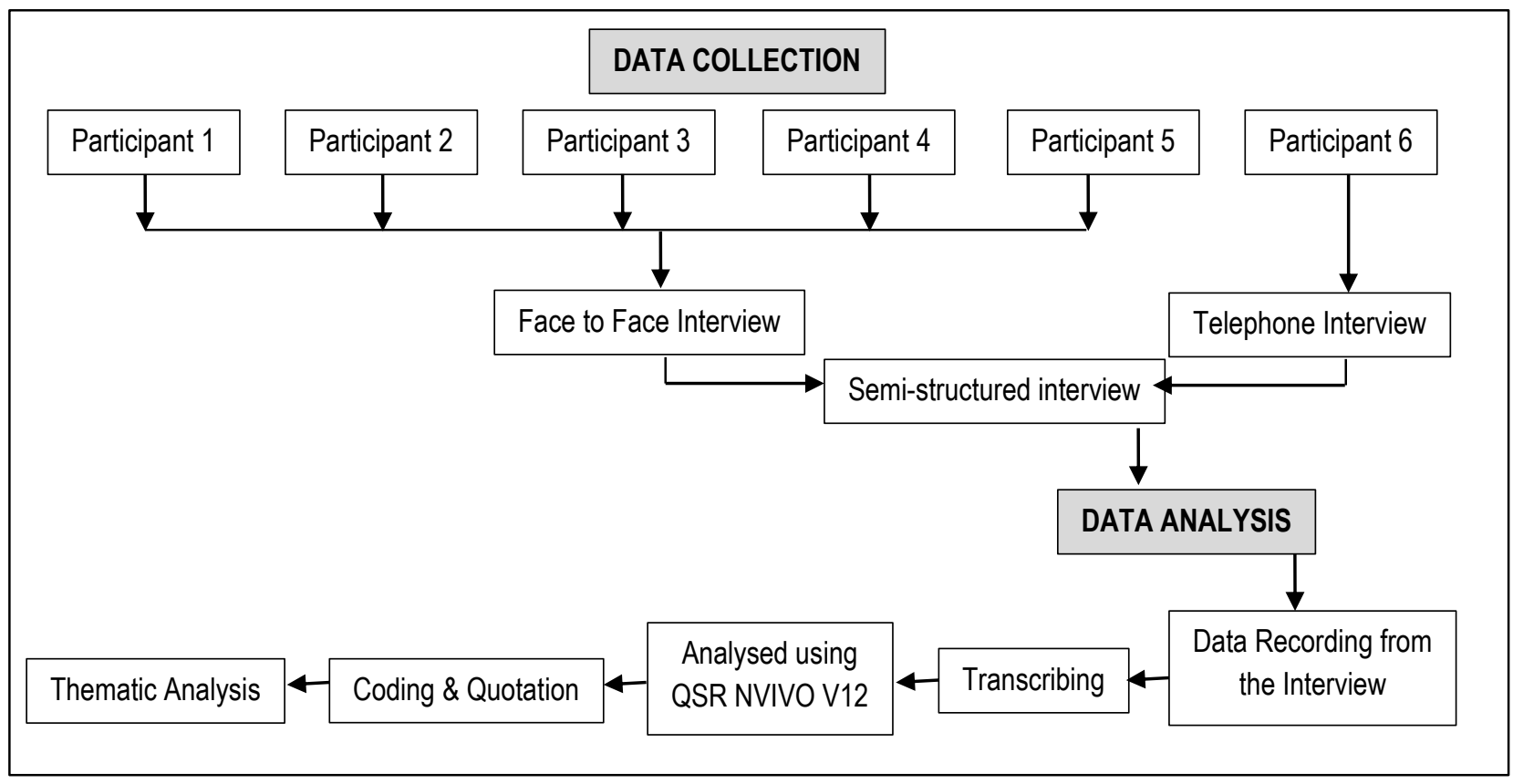

\subsection{Findings and Discussions}

The presentation of the results is according to the thematic analysis based on the verbatim quotes from the study of 6 participants. This study only highlights the key elements in sale and leaseback investments to maximize the returns on property investments dealing with the sale and leaseback arrangements by Real Estate Investment Trusts.

This paper explores the views and experiences of the REIT Managers that are involved in the arrangement of sale and leaseback investments. These views and experience should be taken into account when designing interventions to promote increased sale and leaseback investments among property investors.

It is thus crucial to interpret the limitations of the study findings. The number of participants in this study is low due to the limited number of REIT companies engaged in the arrangement of sale and leaseback investments. As such, the participants are experts, with at least 10 to 25 years of experience in this real estate investment field.

Figure 3 shows the network of responses of the qualitative interviews in terms of the critical elements of sale and leaseback investment arrangements. Identification of the three main themes is in grey color in this survey, which are the critical considerations by the investors before purchasing the property under the sale and leaseback investment agreement. The elements are rental, location, and type of lease.

Most of the participants respond that they must identify the location first before they purchase the property. As participant 1 says:

"...if let say I want to buy an industrial asset let say in Perlis, but the current owner convinces me and says ok he is going to commit for ten years lease, after ten years we still need to keep the asset then what we are going to do with the asset in Perlis."

It shows that the participant is concerned about the usage of the property after the lease ends if the property is located in a suburban area, or not within a prime area. Ang (2017) concurs by saying that building owners may find it challenging to secure new tenants when the leaseback term ends, especially for properties in rural areas not considered as attractive as those in urban areas. Not only that, but the type of property will also influence the suitability of the property in that property location. Moreover, the location factor will also affect the yield of the property, as Participant 4 says:

"If the location is very good, your capital value would definitely increase, unfortunately, because we look at yield, we don't look at the capital value that much"

Most of the REIT Managers are more concerned about the yield received instead of the capital value because they aim to increase their property portfolio, not to purchase and sell the property at the end of the lease. This is proven by Lam \& Tipping (2016) that all risks yield (ARY) is a standard criterion by investors before making property investment decisions associated with the rental return. Participant 5 says:

"...we base on what kind of return/rental income that we are expecting from that property is important to us." 


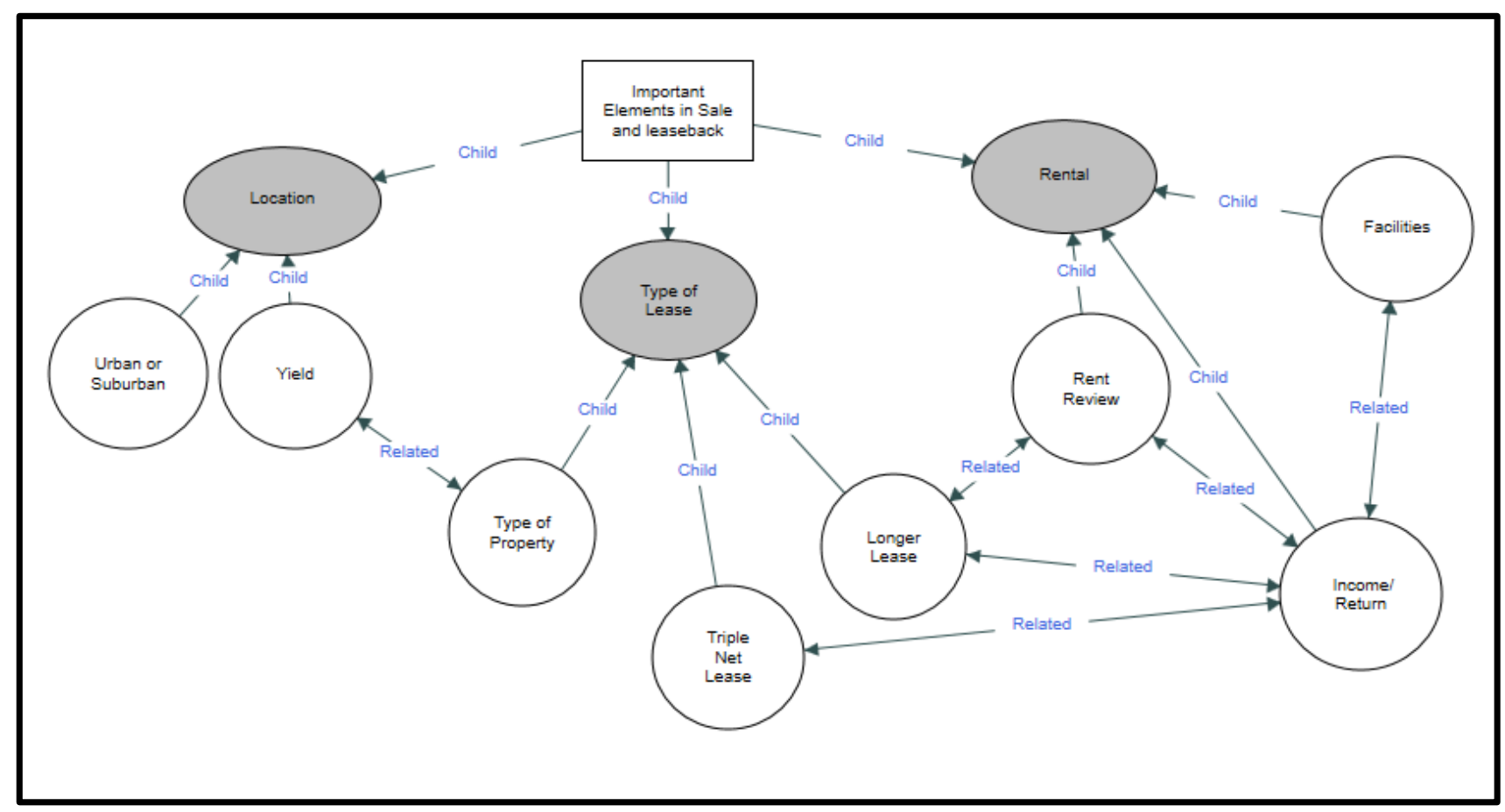

Figure 3: Network of responses in terms of the important elements of sale and leaseback investment arrangements

This is because, according to the guidelines on Listed Real Estate Investment Trusts issued by the Securities Commission, REITs need to distribute at least $90 \%$ of their earnings to the shareholders. That is the reason why the rental income that they receive is more important than the capital value of the property. Participants 5 and 6 have the same opinion

\section{"... the term of lease and renewal of a lease will also influence the rental income of the property."}

Almost all the REIT Managers prefer to have long lease agreements between 10 to 15 years' leases. Sale and leaseback is a relatively safe investment where the risk of a vacancy during the lease period is less due to a long term lease nature (Sirmans \& Slade, 2010; Wilson, 1953; Cary, 1948). Besides, as Participant 2 says:

"...of course, the longer, the better."

Participant 3 , concurs by responding:

"We do not have to worry about the rental income for the long term, for example, 15 years lease. It is already a guarantee rental income that we can receive from the property."

Moreover, due to longer leases, most of the REIT Managers prefer that the outgoings are borne by the previous owners or the tenants themselves as Participant 6 says:

"So far most of our property we go for triple net lease. We do not want to get involved in the operation part because our business only focuses on leasing."

In concurrence, Participant 4 also prefers triple net lease, because she says that:

"...obviously once you take out quit rent and assessment. It's quite a big chunk of your annual expenditure."

All these show that negotiating a triple net lease will also influence the rental income received by the REIT companies as well as dividends received by the shareholders. For a higher rental income, the property needs to have added value to the market rental. This value depends on the quality of the property and the needs of both parties (Grönlund, Louko, \& Vaihekoski, 2008). As Participant 1 says:

"We have at least more or less the same as the market rental, but we also look at the grade of the building, what kind of the facilities were provided, all that will top up the market rental of the building." 
The results of this study show that each of the elements is related to each other. The REIT Manager needs to consider all the elements before he decides to purchase the property under the arrangement of sale and leaseback. When he sells the investment, his concern is on the stream of income from the property and the dividend that will affect the distribution of income to the unitholders.

\subsection{Conclusions and Recommendations}

This study investigates the key elements that REIT Managers need to analyze before getting involved in the arrangement of sale and leaseback. It is heavily base on their practices since they were involved in sale and leaseback investments since 2006 up to 2018 . The study identifies these three critical elements, namely location, type of lease, and rental. The network of responses in Figure 3 shows that each factor is interrelated.

These findings conclude that the REIT Manager needs to make sure that he considers all the three critical elements before deciding to purchase the property. With these vital elements, it is thus possible to maximize returns by professional practitioners and investors in the purchase of the properties by reducing the risks for investment purposes. Nevertheless, REITs are calling for those sales and leaseback arrangements from the robust operation companies to remain high. Concurrently, REIT companies could increase their property portfolios but with low risks due to long term guaranteed rental income.

There are limitations to this study, as there are only 18 REIT companies in Malaysia. Only 7 REIT Managers are involved in the arrangement of sale and leaseback, and willing to participate in this study. Besides that, with the scarcity of literature on sale and leaseback investments in Malaysia, it is necessary to look further afield into other countries practicing sale and leaseback.

This study focuses only on Real Estate Investment Trusts as investors in the arrangement of sale and leaseback investments. Further research may also involve a larger sample size to provide more reliability of the findings. An example, such research may cover other types of investors, such as individuals or organizations that are involved in or practices sale and leaseback investments.

\section{Acknowledgments}

The authors wish to acknowledge the support funds for this research under the Geran Khas Insentif Penyeliaan Perak (GKIPP) from Universiti Teknologi MARA, Perak Branch. We would like to thank all 6 REIT Managers who had participated in this study as respondents.

\section{References}

Ang, H. H. (2017). Managing risk in sale and leasebacks_Focus Malaysia. Focus Malaysia. Retrieved from http://www.focusmalaysia.my/Property/managing-risk-insale-and-leasebacks

Cary, W. L. (1948). Corporate financing through the sale and lease-back of property: Business, tax, and policy considerations. Harvard Law Review, 62(1), 1-41

Grönlund, T., Louko, A., \& Vaihekoski, M. (2008). Corporate real estate sale and leaseback effect: Empirical evidence from Europe. European Financial Management, 14(4), 820-843. https://doi.org/10.1111/j.1468-036X.2007.00417.x

Hamzah, A. H., Rozali, M. B., \& Tahir, I. M. (2009). Empirical Investigation on the Performance of the Malaysian Real Estate Investment Trusts in Pre-Crisis, During Crisis and Post-Crisis Period. International Journal of Economics and Finance, 2(2), P62. https://doi.org/10.5539/ijef.v2n2P62

Hunsaker, B. (2012). Making The Most of Sale and Leaseback. United States: International Franchise Association.

Lam, T. Y. M., \& Tipping, M. (2016). A case study of the investment yields of high street banks. Journal of Property Investment \& Finance, 34(5), 521-534. https://doi.org/10.1108/JPIF-03-2016-0019

Ling, N. L. F. J. (2012). Analysis of Factors and the Impacts of Sale and Leaseback Transaction. Procedia - Social and Behavioral Sciences, 36(June 2011), 502-510. https://doi.org/10.1016/j.sbspro.2012.03.055

Ruslan, S. M. M. (2019). The financial performance of islamic real estate investment trusts (REITs) in Malaysia. Asian Academy of Management Journal of Accounting and Finance, 15(1), 191-220. https://doi.org/10.21315/aamjaf2019.15.1.8

Saldana, J. (2009). The coding manual for qualitative researchers. London: SAGE Publications Ltd.

Sanderson, D. C., Shakurina, F., \& Lim, J. (2019). The impact of sale and leaseback on commercial real estate prices and initial yields in the UK. Journal of Property Research, 36(3), 245-271. https://doi.org/10.1080/09599916.2019.1642370

Saunders (2016) Research Methods for Business Students. Harlow-Munich: Pearson

Sirmans, C., \& Slade, B. (2010). Sale-leaseback transactions: Price premiums and market efficiency. Journal of Real Estate Research, 32(2), $221-241$.

SC (2019) List of listed real estate investment trusts (As at 31 December 2018) https://www.sc.com.my/api/documentms/download.ashx?id=bf905fdd-b9c5-4a95-bdf3$6 \mathrm{c} 953 \mathrm{~d} 7 \mathrm{~d} 43 \mathrm{c} 0$

Thomas G (2011) 'How to do Your Case Study - A guide for students and researchers', Cornwall: SAGE Publications.

Wells, Kyle S. \& Whitby, R. (2012). Evidence of Motives and Market Reactions to Sale and Leasebacks. Journal of Applied Finance, (1), 57-71. 
https://doi.org/10.2139/ssrn.1081461

Wilson, J. A. (1953). Sale and Lease-Back - A Re-Appraisal. Case Western Reserve Law Review, 4(4), 318-335.

Wong, Y. M. (2015). Malaysia REIT: First Decade Development and Returns Characteristics. Ssrn, (January). https://doi.org/10.2139/ssrn.2555174 Yin R K (2009) Case Study Research: Design and Methods. Sage Publications, California. 